\title{
From the Belief of the Immortality of the Soul, the Blessing or the Harassing of the Soul Towards People to the Worship of the Souls of Vietnamese People
}

\author{
Vu Hong $\operatorname{Van}^{1}$ \\ ${ }^{1}$ Faculty of Basic Science, University of Transport and Communications, Vietnam \\ Correspondence: Vu Hong Van. E-mail: vhvan@utc2.edu.vn
}

Received: December 19, 2019

Accepted: January 21, 2020

Online Published: February 27, 2020

doi:10.5539/ass.v16n3p1

URL: https://doi.org/10.5539/ass.v16n3p1

\begin{abstract}
Does the soul exist? If there exists where it is, what it is doing and if the soul does not exist why is it still appear in the daily lives of so many people, so many generations and many places in the world. Why is it so important for so many countries in the world to believe in the immortality of the soul and death? Faith in the dead and the next generation depends largely on a person's religion and culture, on a community of people. For many Vietnamese, this belief goes from the belief that the soul only reaches its ultimate goal after many reincarnations, to the idea that life will now determine its final destiny. Consequently, one person can feel confident that he will eventually merge with the ultimate reality after death, others will surely reach Nirvana, and others will believe that he will be rewarded in heaven. So what is the truth? Because our beliefs affect our attitude, actions, and decisions, are we not interested in finding answers to that question? The dead are not finished but their souls still exist. Depending on the behavior of those who live with those who have died, they (those who are still alive) may be blessed by the soul or punished by the soul, encountering unfortunate things in life. This study provides a discussion of whether or not the existence of the immortal soul and the blessing or harassing of the soul for human life. How can humans limit the harassing and many blessings from the soul? Why does belief in the blessing and harassing of the soul become such a popular custom of worship among Vietnamese people?
\end{abstract}

Keywords: belief, immortality of the soul, the blessing or the harassing of the soul, worship of the souls, Vietnamese people

\section{Introduction}

The concept of the soul is closely related to the notions of life after death, but there are very different ideas, even of the same religion, about what happens to the soul after the body dies. Many people follow certain religions and philosophies for the soul to be immaterial (Frede, 1956; Bremmer, 1983; Ngoc, 2002) while others think that the soul may have a material component (Tocarev, 1994; Sam, 1995) and some even try to find the block amount (weight) of the soul (Lang, 1974). Normal souls (but not always, as explained below) are said to be immortal (Kerferd, 1971). Socrates says the soul is a crystal (Essence). Plato states that the soul consists of the reason (Logos), affection (Thymos) and craving (Eros) (Algra, Barnes, Mansfeld, \& Schofield, 1999). Aristote defines the soul as the activity of a living body and assumes that the soul will disappear when the body is no more, just like the activity of a knife is to cut, when the knife is damaged the cutting activity ceases again (Algra, Barnes, Mansfeld, \& Schofield, 1999). Because of the concept of the soul in different ways, people still argue about whether or not there is a soul. Often the soul is understood as the spirit, the crystal of the person, as opposed to matter, to any biological organ of the body (Tien Duc Association, 1931; Thu, 1997; Thanh, 2018).

The Bible, the oldest book in the world, traces the history of man back to the time when the first human soul was created. Bible teachings are not infected with human philosophy and tradition. The Bible tells the clear truth about the soul: Your soul is a friend, the dead are completely no longer present, and those who are in God's memory will be resurrected at his appointed time. What does this knowledge mean to you? Jesus Christ said to his disciples: "You will know the truth, and the truth will set you free" (John 8:32, NW) (Christian, 2013). Yes, the truth has a liberating effect. But what does the truth about the soul free us from (Christian, 2013)?

In general, beliefs and religions often think that the soul is sacred and immortal. Judaism, Christianity, Islam all think that the soul is immortal, given by God to each person as life, if a person lives up to God, when he dies, his 
soul it will be about living happily ever after with him; on the contrary, if he does evil and does not believe in God, his soul will be punished and suffer in hell.

For the majority of Vietnamese people, for a long time, in their life, they always perceive that "everything has a soul", in which the soul of man is the most sacred and important. It is not known since when, in the life of Vietnamese people, they have formed a habit of worshiping the souls of the dead and become a typical folk belief of Vietnamese people.

The custom of worshiping souls is a kind of folk belief that has existed for a long time and is very popular in the spiritual life of the masses in North, Central and South Vietnam. Thanks to the recognition and clear rules of the worship in the legal documents of feudal dynasties through the historical periods of the nation, this belief was strengthened, maintained and developed until today.

During the course of existence and development, like other forms of folk beliefs, the acquisition, adjustment, and usage of the world's cultural movements, beliefs and religions are inevitable. In Vietnam in particular and in East Asian countries in general, Buddhism and Taoism have a great influence on all aspects of people's lives, especially in religious activities. In traditional Vietnamese thoughts, along with Confucianism, Buddhism and Taoism were introduced very early (around the end of the second century). These religions did not face native beliefs, developed freely and had a great impact on the religious life of Vietnamese people from the past to till the present.

The Vietnamese nation has a democratic tradition, which promotes harmony and desire for discovering new things. The ideology is not bound to a certain framework; therefore, since Buddhism and Taoism were introduced into Vietnam, ancient Vietnamese people have actively opened the door, welcomed the essence of that ideology, filtered, integrated and transformed it into a unique one suitable for the living conditions to serve the common interests of the nation. One of those harmonies was clearly shown in the custom of worshiping souls, which is popular in almost every part of Vietnam.

In addition to Buddhism and Taoism, Vietnamese beliefs are also influenced by other international religions such as Christianity, Protestantism, and Islam. However, the most powerful influence on the religious life of Vietnamese people is probably Buddhism (Tien Duc Association, 1931; Giau, 1973; Lang, 1974) and Taoism (Ngoc, 2002; Hinh, 2007).

As a kind of folk belief of Vietnamese people, the custom of worshiping souls not only contains cultural and moral values but also shows the outlook on life and the world of a large number of Vietnamese people. Despite its certain negative effects, the custom of worshiping souls has a positive influence on the life of each individual, community, and society. Apart from typical forms of folk beliefs such as the worship of mother goddesses and the worship of village tutelary gods, which are very popular in the lives of the whole Vietnamese people, the worship of souls is also a way to show good values of Vietnamese people and satisfy the spiritual needs of each individual, family, and community.

\section{Research Methodology}

The author is a person who was born and brought up in the rural areas of Vietnam. When I was children, I have witnessed funeral rituals in my families: worshiping the deceased (grandfathers, grandmothers, aunts, uncles, etc.) and worshiping the souls of people who died in rivers, markets, wars, etc. in communal temples and in pagodas. With my innocence at that time, I thought that the dead members of my families were not gone, still existed and sometimes visited the living ones on fifteenth day of the lunar month (the full-moon day), the first day of the lunar month, Lunar New Year's Day, and especially their death anniversary (the date when they died). For those who were not worshiped, there would be one day when they were "offered food"; that was the wandering souls' day (the fifteenth day of the seventh month of the lunar calendar) every year.

When I grew up and started to choose my career, I decided to study philosophy and religion and had better conditions to further study those rituals. In order to search for the materials to write up my article, apart from studying ancient bibliographies, the author also conducted practical surveys in many localities and directly got involved in the worshiping rituals in all three Northern - Central - Southern regions of Vietnam. Based on my own understanding of folk beliefs and religion, as well as the research results on the worship of souls of Vietnamese people, the author conducted the study titled "From the Belief of the Immortality of the Soul, the Blessing or the Harassing of the Soul towards People to the Worship of the Souls of Vietnamese People".

\section{Views on the Soul of Vietnamese People}

In the folk belief of Vietnamese people, a living person is a combination of two parts: the "body" and the "soul". The body can be understood as the physical, visible part of a human being. The soul is an immaterial, abstract 
part related to people's spirit, thoughts, and feelings.

According to that folk belief, human beings have two groups of souls: three souls and seven spirits. Women have two spirits as many as men; so they have nine spirits. These souls settle in human beings and mingle with the bodies to form living human beings. Humans (bodies) receive the souls on the date of birth or the date of conception.

Souls are only spiritual souls and spirits are material souls. Souls are more sacred than spirits, so when someone is alive, due to respect, people avoid talking about his or her soul. Spirits can be both beneficial and harmful in everyday life. Spirits have different characteristics, depending on whether a person has a good or bad spirit. Some people have good spirits while others have bad and evil spirits. Good spirits bring happiness and good luck, so people try to meet people with good spirits. Bad spirits have negative effects on everything, so people try to stay away from people with bad spirits.

There are also different viewpoints about souls among the researchers studying Vietnamese folk beliefs. The Dictionary of Vietnamese Culture and Traditional Customs defines souls as "the souls of the dead in the underworld, which are possible to stay around their living relatives" (Y \& Huy, 2011, p. 17) Souls may also be the souls of the dead drifting from other places, whose identities are unknown and are buried by the villagers. Souls are also "the wandering souls of all kinds from kings to common people, from the rich to the poor" (Trang \& Tuong, 1999, p. 138) "People believe in ghosts and gods, so they think that the dead have souls and senses like the living, and in the underworld, there are also happy or unhappy people like on earth. Those whose children keep worshiping will have a place to come back whereas unfortunate or heirless people who are not worshiped will feel distressed in the underworld" (Binh, 2005, p. 151).

According to Buddhism, human beings are combined from five elements called Skandhas (five aggregates) including: form, sensation, perception, mental formation, and consciousness. Of these elements, the form is the tangible element (material element) that makes up the physical part of a human being. The remaining elements, including sensation, perception, mental formation, and consciousness, are invisible elements, corresponding to the elements of feeling, perception, reason, and awareness. The combination of these four invisible elements makes up the spiritual part of a human being.

In its philosophy, Buddhism believes that life is a cycle with the unit of "Kalpa" (a cycle of birth - death). All happy or suffering conditions of earthly people are effects of corresponding causes, called "sowing what you reap" (Giau, 1973; Binh, 2005) "Causes" can be created from previous Kalpas or in the present Kalpa. If people do not take enough "effects" while they are alive, they will take them in their next Kalpa (Binh, 2005).

According to the law of cause and effect in Buddhism, after people die, their souls will leave their bodies. Their souls, depending on their karmas (created when they were alive) will be reborn according to "sixth paths" (six ways), including: Celestials (the realm of gods): Buddha, Bodhisattva, etc.; Human beings: people (rich, poor, happy, unfortunate, etc.); Asuras: Ghosts and spirits (intermediary level); Animals: buffaloes, cows, pigs, etc.; Hungry ghosts: often live in wet, dirty places; Hells: way of the wicked (the underworld, corresponding to 18 layers of hell).

Also from Buddhism's point of view, after their death, people's right-doings and wrong-doings will be judged by "Ten Kings of the hell" (ruled by Earth-Store Bodhisattva) within seven weeks, corresponding to seven gates of the hell (Binh, 2005; Thanh, 2018). Therefore, in the funerals of Vietnamese people, there was a forty-nine-day worshiping ceremony, in which the souls are sent to pagodas where the monks will pray for their freedom from sufferings. According to the concepts of "samsara - cause, and effect", after forty-nine days, the souls will be under the control of the officials in the underworld. These officials will carefully consider all big and small things that people did when they were alive to decide how they will be reborn: become human beings, become animals or be exiled to the underworld and subject to severe harassing.

Thus, the view of the soul in the East and the West has many similarities that are the immortality of the soul, the soul capable of influencing those who are still alive. Perhaps because of that, the worship of the soul has existed in the practical life of humanity both in the East and in the West.

\section{Soul Classification}

Through the above study, it can be seen that although there are different interpretations of "body" and" soul", they are similar in one viewpoint: When people die, there will be a separation of their souls and their bodies. All the conceptions show that when a person dies, his or her body will dissolve over time whereas his or her soul will continue to exist.

With the theory of "samsara - cause and effect", it is obvious that Buddhism indicates the infinite cycle of the 
existence of souls. This is the basic difference between the Buddhist concept and the relief of worshiping souls of Vietnamese people. Based on the viewpoints of Buddhism, when grandparents, parents, and relatives die, their souls must follow the samsara, life afterlife. All the credit - sin, good - evil, good - bad of each individual when he or she is alive will lead to how his or her soul goes to the next life. According to Buddhist teachings, with the unlimited power of Buddha Dharma, the ten kings of hell will not miss any souls. Accordingly, it is impossible for ancestors' souls to "go home" with their descendants or forsaken souls or hungry ghosts to wander on earth.

Despite the contradiction in whether there is the existence of souls around the living, over the past thousands of years since Vietnamese people accepted Buddhism in their religious life, they still maintain both philosophies of life, interweave and blend them into a collection of mixed beliefs which shows the harmony of Vietnamese people through many generations.

With studies, hundreds of years ago (Lang, 1974; Binh, 2005; Thanh, 2018) and even today (Duy, 2002; Anh, 2005; Hinh, 2007) show that Vietnamese people divide souls into two types: souls with owners (relatives) and souls without owners (forsaken souls). Souls with owners, i.e. those with usual death (death due to old age, sickness, or the standards of longevity on earth specified in the Crux's book) are worshiped by their relatives and descendants. Forsaken souls are lonely souls without being worshiped by anyone. who had no descendants after his death despite having been buried as usual and taken to the ancestral spirits' residence, but did not know where to go due to the absence of descendants, should become a forsaken soul. When hungry, no one offered a bowl of rice, when cold, no one sent a coat. Vietnamese Dictionary says, "A forsaken soul is the soul of a dead person without being worshiped by his or her relatives" (Phe, 2005, p. 87). Having a baby does not mean that after death becomes an ancestral soul in the house, there is also an important condition that the child can live, mature, get married and reproduce. Therefore, it is the responsibility of the parent to give birth to a child who can take care of the child and help the children to form an adult family. In this way, it is ensured that the worship continues, creating generations of ancestor worship. With that in mind, Vietnamese people take care of their children very carefully, teach them traditional knowledge, and organize marriage for them when they reach their age. If conditions permit, they also do their best to take care of married children with new decent accommodation and take care of great-grandchildren. The generations of the family go on and on, the dead never become evil spirits, while this can happen at any time if the offspring do not continue to multiply.

Another condition is that the person naturally dies due to old age or illness, and is buried as usual. For Vietnamese people, suicide, drowning, death, traffic accident, fire death, difficult childbirth, severe death or starvation in the street market, etc., all those deaths are abnormal deaths to these causes are not classified as ancestral souls that become wandering souls. Elderly people are invited by the family members to come and preside over the funeral and chant "prayers". How to bring dead souls to the right place of ancestral souls is important. Therefore, the Vietnamese people have to organize a "good-soul" chanting ceremony to lead the souls of the dead step by step to their destination. So the "tiễn hồn" (sending off the dead to the land) is also known as the "guide for the soul". Only after going through certain funeral rites and reaching the residence of ancestral souls, the souls of the dead will be considered ancestral spirits in the home.

All the above biochemical viewpoints have created the existence of souls after death in the minds of Vietnamese people. Therefore, a long time ago, the habit of worshiping the dead (souls) was formed in the daily spiritual activities of Vietnamese people. That habit has lasted for a long time, gone through many generations and become the custom of Vietnamese people. However, along with the changes of the time and the exchange and adaptation of cultural flows in the world during the integration period, this worship custom has changed compared to the original form and both positively and negatively affected the awareness as well as social behaviors of part of Vietnamese people.

\section{Faith in the Blessing and the Harassing of the Soul}

Normally, dead souls that are not of the ancestor's souls are considered to be ghosts, that is, death due to shipwreck, war dead, suicide, dead in the streets, etc. or have no descendants of worship. Such dead people are called abnormal deaths. Such unusual deaths are said to be unable to return to their homes. The devil has no shelter, there was no food to eat, no water to drink, no clothes to wear, etc. and so on wandering all day long, no one is worshiping. Therefore, these souls will generate hatred towards the living. In Vietnam, the 7th lunar month every year, according to the popular concept called "the month of the soul" or the month of "opening the grave" (Figure 1). According to folklore, the seventh lunar month is the month in which "the devil is most active". 


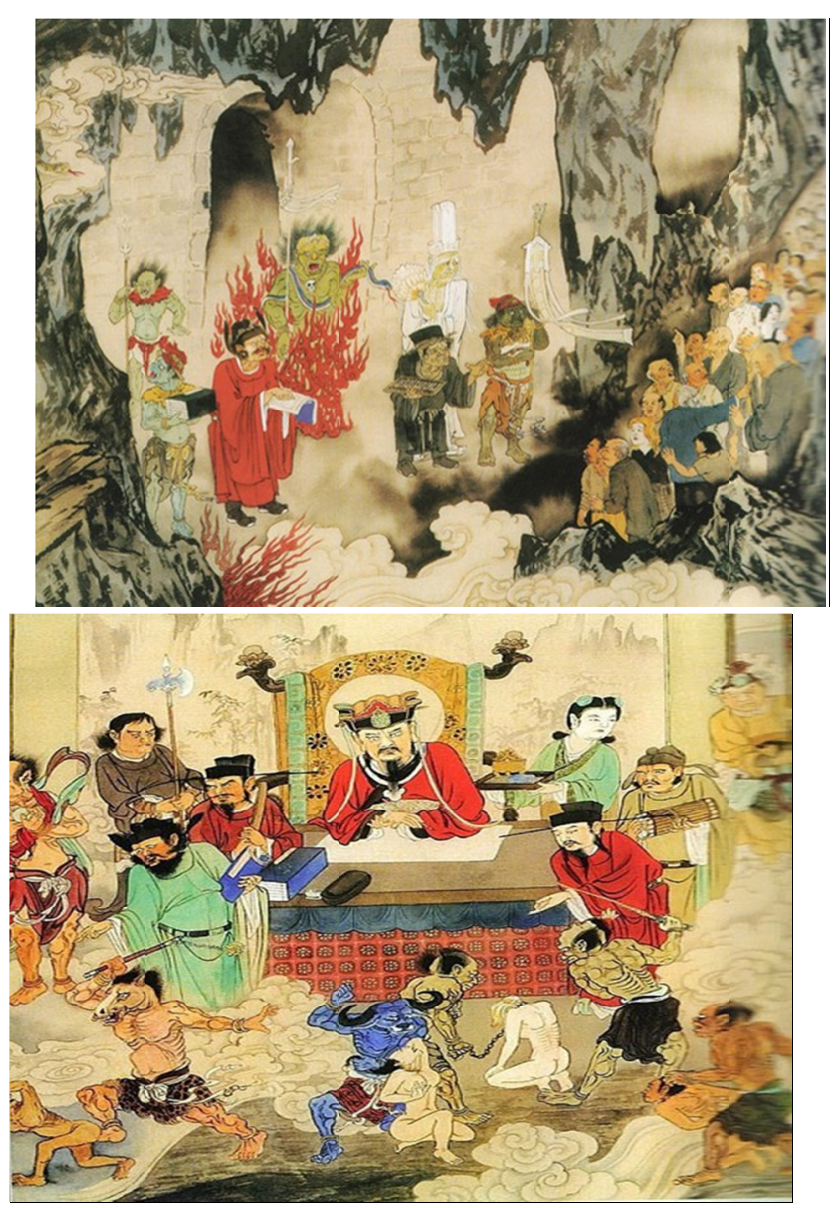

Figure 1. Ritual opening the hell door (Source: VOV)

According to many researchers (Giau, 1973; Duy, 2002; Ngoc, 2002; Hinh, 2007), the origin of the month of the soul comes from King of Hell opening of the "Devil Gate" on the 2nd of July (lunar calendar) every year so that the hungry ghosts can return to earth and then Full Moon in July to return. People think that July is the devil's month, which does not bring good luck, so most of the wedding, starting to build house, shopping, traveling away, etc. are avoid July. After coming out of hell, hungry demons will wander around, meeting people who will harass people, meeting cattle and poultry that will harass cattle and poultry. People who are harassed by demons may get sick, suffer, business risks, trade, travel, may face accidents, etc.; pets that are disturbed by demons can get sick, die, etc. Therefore, according to folklore, the earthly people must offer rice porridge, rice, and salt to the hungry ghosts so that they do not disturb everyday life.

Also according to many researchers (Giau, 1973; Duy, 2002; Ngoc, 2002; Hinh, 2007) since ancient times, Vietnamese people have believed in the existence of ancestral souls. Ancestor respect went deep into the hearts of the Vietnamese people who do not know from when they were born. Every anniversary, on the full moon, especially Lunar New Year, on the ancestral altars of every Vietnamese family is offered a lot of flowers, fruits, etc. to show their gratitude. Thank you and remember the ancestors, desiring ancestral souls bless their descendants. The spirits of ancestors always bless their children, wish them health, happiness, luck in life, etc. However, ancestors will punish if the descendants do not worship well. Therefore, in order for their ancestors to bless, the descendants will have to worship very carefully. There are many large and small rituals in worshiping the spirits of ancestors. The ancestor will be worshiped on a very solemn altar with enough re-plants, flowers, incense, etc. Every year, on the death anniversary, Lunar New Year of Vietnamese people, graves of ancestral will be taken care of very carefully (Figure 2). 


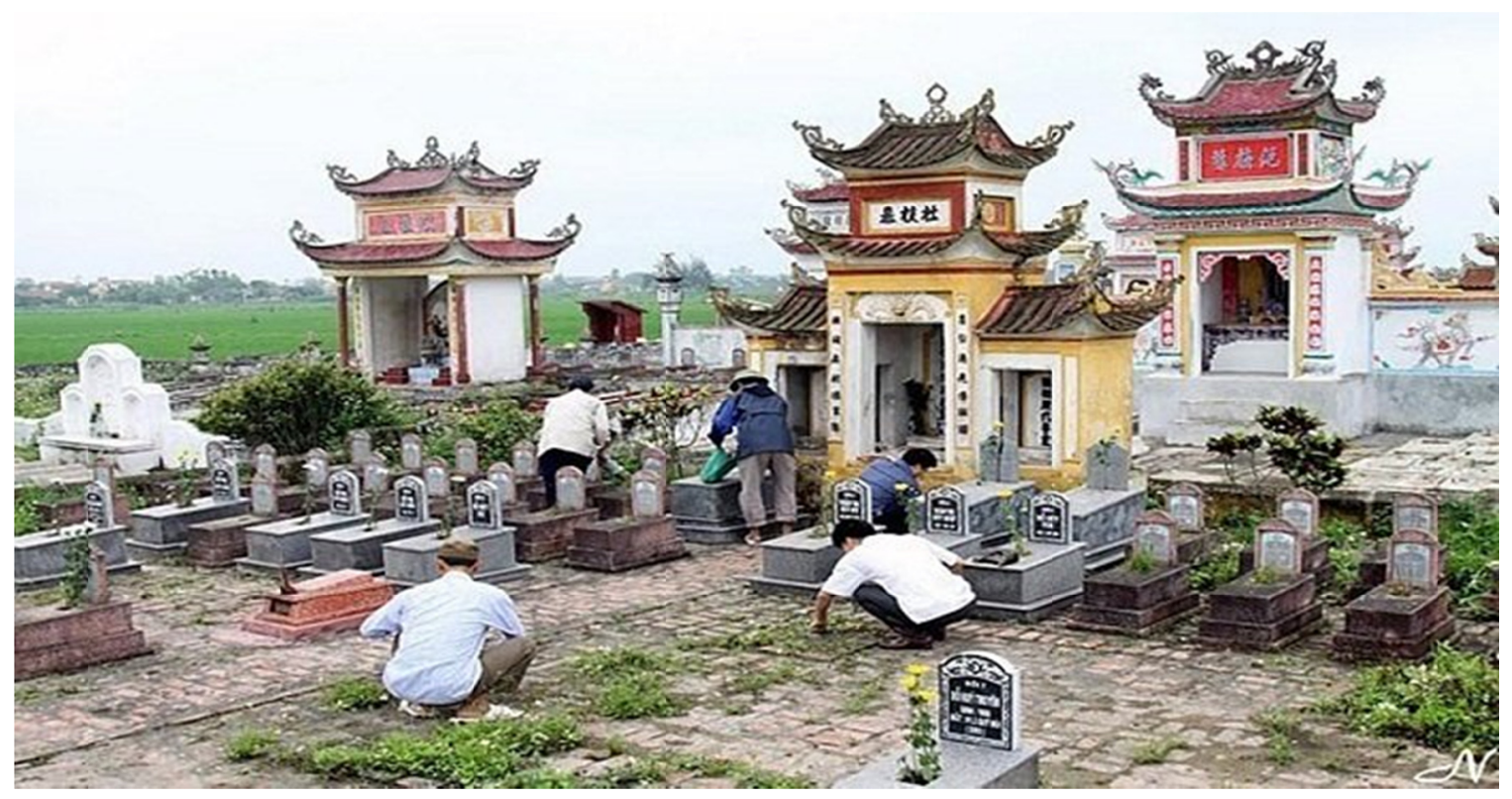

Figure 2. The custom of visiting ancestral graves on the occasion of Lunar New Year

\section{Custom of Worshiping Souls of Vietnamese People}

\subsection{Custom of Worshiping Souls in the Families (Worship of Ancestors)}

"According to ancient Vietnamese people, death is not the end. A person is dead but his or her soul still remains and usually "frequents" the family. The body dissolves, but the soul is immortal" (Anh, 2005, p. 11). Family members (grandfathers, grandmothers, fathers, mothers, brothers, sisters, etc.) who are dead still have needs and desires like living. "People also believe that life in the underworld is the same as life in on earth. The dead also need such things as when they were alive. In other words, the dead also needs to eat, drink, spend money and live in houses like the living" (Anh, 2005, p. 11).

Right after a person's death (the soul has left his or her body), to lighten the steps of the soul when leaving the body, the living people (relatives in the family) will have to light candles, burn paper money or gold to pay the soul's travel expenses to the underworld and make offerings of food and drinks to reduce the hunger and thirst of the soul.

People burn things made of paper exactly like the things living people need like furniture, horses, servants, etc. to the souls; Rich people even burn paper bicycles, motorbikes, cars and sometimes planes. In the current society, people also burn mobiles and tablets to souls. The sacred duty of a filial son is to meet all the needs of his deceased ancestors. In Vietnam, the person who performs the above rituals is usually the eldest son (or religious grandson) of the family. In addition, children and grandchildren can also set up their own altars at home. However, on important days such as death anniversary, grave transfer, etc., they must gather at the eldest son or the patriarch's home.

It can be said that "The custom of worshiping ancestors is the most popular belief of Vietnamese people. It comes from the conception that the souls of the dead still exist in this world and affects their descendants' lives" (Ngoc, 2002, p. 189). The worship of ancestors often takes place on the death anniversary, holidays and Lunar New Year to commemorate the dead, show admiration and respect and pray for all good things to come. Vietnamese people take gratitude as their moral foundation, that is, descendants must be grateful to those who gave birth to them. The death anniversary of ancestors reminds descendants of the date when they died and creates the basis for family relations. Nobody knows whether there are souls or not, but one certain thing is that descendants must be grateful to their ancestors (Figure 3). 


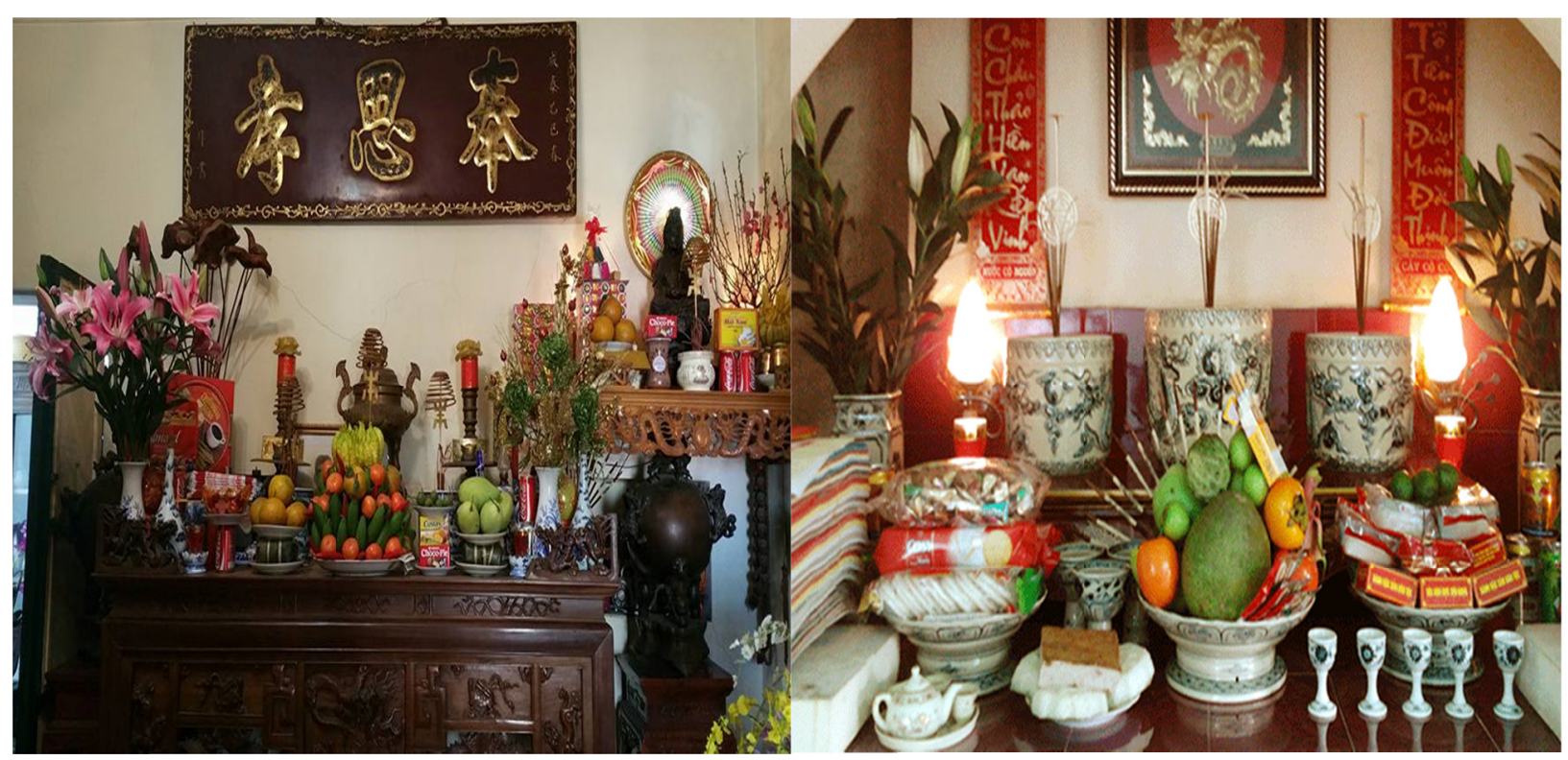

Figure 3. Altar where the ancestor worship in the family

Vietnamese people make offerings to their ancestors' souls on their date of death (death anniversary), which is usually calculated according to the lunar calendar. Descendants believe that it was the date when their ancestors' souls went to the afterworld. Not only on death anniversary, but the worship of ancestors is also carried out regularly on the first and the fifteenth of lunar months, and holidays. When there are important events in the house such as getting married, giving birth, building new houses, going away for work, taking examinations, etc., Vietnamese people also make offerings to their ancestor souls to report and pray for good luck or to show gratitude when their work is successful.

The nature of the worship of the ancestors' souls of Vietnamese people originates from the belief that the living and the dead have a close relationship with each other. Descendants pray for their ancestors and ancestors to protect and guide their descendants. So, the worship is considered a connection between the living and the dead (San, 1998; Anh, 2005; Thanh, 2018). Beliefs in the death suggest that "tử tuất quy thổ, cốt nhục tê ư, hạ âm vi giả thổ, kỳ phí phát dương ư thượng vi chiêu minh" (the dead people were buried in the ground, their bodies were decomposed, melted, buried in the ground were only fake, the soul was allowed to fly to the sky). This means that people who die will surely return to the earth; their flesh and bones dissolve into the ground and their souls fly high in the air. "The worship of ancestors is a belief since people consider their ancestors' souls as tutelary deities that protect them in their whole lives" (Duy, 2002, p. 191).

\subsection{Custom of Worshiping Souls outside Community (Worshiping Forsaken Souls)}

In the mysterious world, there are abandoned souls that wander or have no relatives and friends. These are the souls of unlucky people who died from accidents or poverty on roads, at markets and their bodies were not buried, worshiped and looked after. These souls wander behind dark clouds, in drizzles, or lie on tree branches. These are also the souls of people who drowned in rivers and seas, hanging about the places where they died to wait for others to die. Those are called forsaken souls. This led to the custom of worshiping souls outside the community.

The worship of souls outside the community also originated from the belief that these souls can also adversely affect the lives of living people. With the fear that these souls will ruin their business, people worship them so that they will create favorable conditions for their work. In addition, the worship of forsaken souls is also a form of seeking security, praying for good crops and praying for the peace of the country and village.

According to the folk concept, since being worshiped by no one, these lonely souls are left hungry and cold and often wander and spread woes to earthly people. In particular, for people who die from injustice, their souls still bear a lot of anger, so they become group "ôn hồn dịch lệ" (those who die without anyone worshiping, the soul wanders in the earthly realm to ask for food) to harm people. Therefore, earthly people must make offerings to them (Figure 4). "It is believed that those who are not worshiped must rob the porridge put in banyan leaves in the soul offering ceremony which is often held in summer or after summer, as well as on the full moon of July or the end of the year. Robbing porridge in banyan leaves is a misery of the souls of the dead; people without 
children are often insulted by enemies to be robbers of porridge in banyan leaves" (Anh, 2005, p. 51). "In three summer months, on the first and the full moon of each lunar month, people cook porridge, wrap it into banyan leaves and leave these leaves with porridge inside along the roads, which is called worshiping all souls. So the customs of the Vietnamese people said that robbing porridge of Da leaves is saying people without children (Binh, 2005, p. 149).
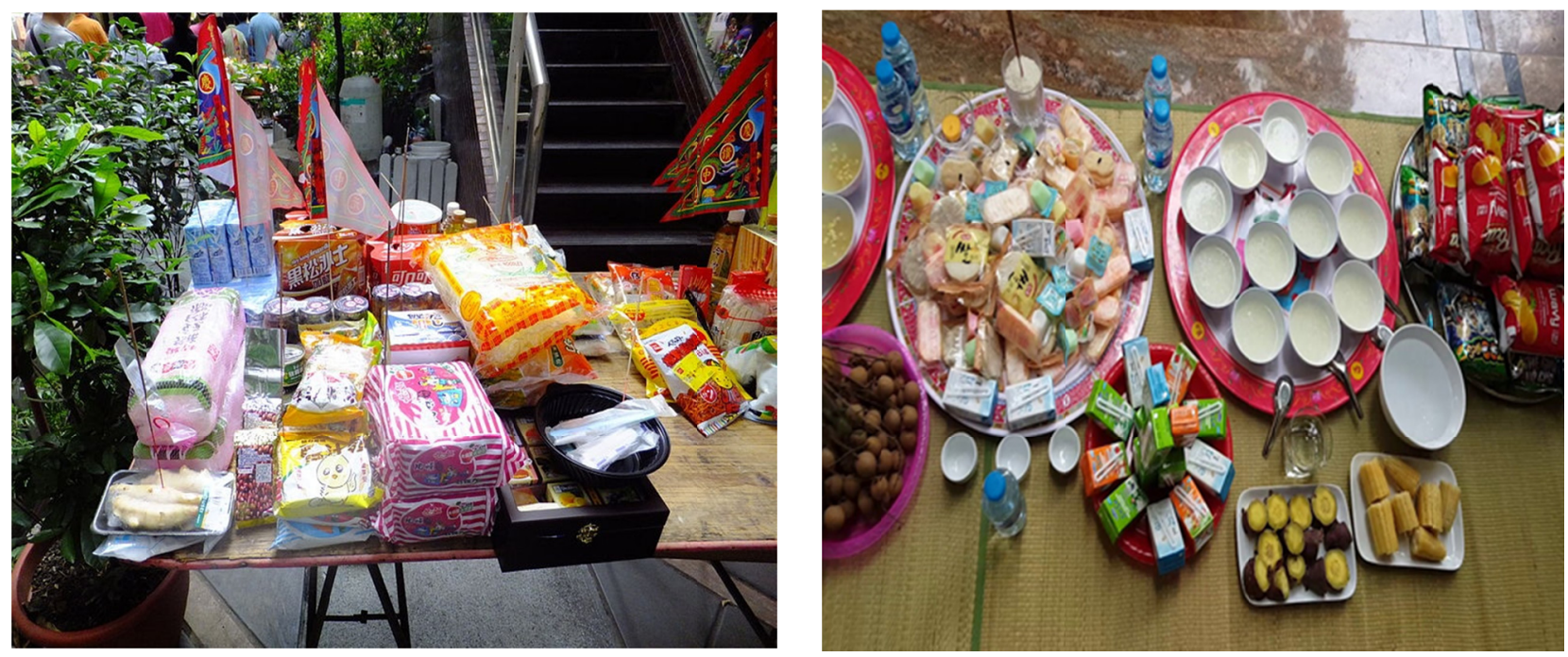

Figure 4. Items to worship souls outside community

Thus, this belief has a great humanistic meaning. It is a deep sympathy for the living towards the dead and the gratitude towards the ancestors who contributed to reclaiming land, building villages and keeping the villages peaceful. There are many different forms of worshiping forsaken souls. Many people just make offerings but do not worship, which is often common among families and individuals. There are forms of worship with worship places (small temples), which are often popular in villages and communes. "The souls and hungry ghosts that are not worshiped often wait at these offerings and rob some porridge to eat. At pagodas and temples, people who do charity often organize worshiping ceremonies for forsaken souls so that these souls have a place to enjoy" (Anh, 2005, p. 51). "In many places, every year on the full moon in July, or in the communal house, or in a voluntary association, set the colon to make a vegetarian offering, offering two, three or five days" (Binh, 2005, p. 149).

This viewpoint has created the belief in the reward and harassing towards good souls and evil souls in the minds of part of Vietnamese people. If people do good things, "improve themselves" and "accumulate virtues" when they are alive, their souls will be returned to the Buddha realm, "stay at pagodas", or will be reborn as human beings again. For those who do bad things, "harm others" and create "evil karmas", their souls will be exiled to the hell or be punished based on their crimes.

\section{Appearance of the Custom of Worshiping Souls of Vietnamese People}

Nguyen Lang in Vietnam Phat Giao Su Luan (Vietnamese Buddhism History) said that "The ceremony for freeing hungry ghosts from sufferings originated from India and was introduced and prevailed in China in the Tang dynasty by Bat Khong Kim Cang (Amogha), also known as Bat Khong Tam Tang, from North India, a famous Dharma heir of Mat Giao (Kim Cang Thừa - Vajrayāna) disseminate" (Lang, 1974, p. 412). With the above comments, that ceremony was actually the Ghost Ceremony (the ceremony for freeing hungry ghosts from sufferings), not the offering ceremony for souls in general.

However, we have not seen any documents showing exactly when the ceremony for freeing hungry ghosts from sufferings appeared in Vietnam. According to Nguyen Lang, this ceremony was widely disseminated in the Tran dynasty. It was written in Dai Viet Su Ky Toan Thu (2004) that this food offering ceremony was introduced into Dai Viet in 1302 by a Taoist named Hua Tong Dao. "At that time, there was a Taoist from the North called Hua Tong Dao following a merchant ship to our country and stayed at Yen Hoa wharf. The witchcraft and worship became popular since then" (Dai Viet Su Ky Toan Thu, 2004, p. 92).

In 1320, the monk Phu Hue organized an altar at Pho Minh Pagoda in the palace to pray for Emperor Tran Anh Tong to live longer. "Then queen mother Bao Tu asked Phu Hue to come to Phổ Minh Pagoda to open the Hoi Quan Đinh (Abhiseka) (Dai Viet Su Ky Toan Thu, 2004), a Buddhist ritual, which use water or shampoo to wash the top of one's head. "When the illness of Emperor Anh Tông just became worse, Pho Hue wanted to meet to 
present the life and death" (Dai Viet Su Ky Toan Thu, 2004, p. 115).

According to Dai Nam Nhat Thong chi, in Nghe An and Quang Binh provinces, "In 1449, the temples for worshipping souls were built but no one made offerings. In 1464, the offerings were prepared to sacrifice to souls and were divided into upper, middle, and lower levels like the offerings made to all gods; every year, the mandarins were ordered to make offerings in three seasons (spring, summer, autumn) and this became the custom" (Hinh, 207, p. 75). According to Phan Huy Chu, "This ceremony began from the beginning of the Le Dynasty, continued and remained unchanged" (Chu, 1992, p. 143).

In Hue, on the 23rd of the fifth month of the lunar calendar, people in Hue solemnly organize a ceremony to worship souls. This ritual is organized for both family and community people in the same area, ward, district, etc. The ceremony of worshiping souls in Hue is organized in such a solemn manner was because in 1885 the citadel was lost to the French. The period of 1883 - 1885 was the most sensitive period in the history of Vietnam in the Nguyen Dynasty (An, 1972; Giau, 1973). In 1883, after the French fired a gun into Thuan An, Hue Citadel fell into a dangerous position and the court was afraid and nervous. At this time, only Ton That Thuyet was determined to maintain the standpoint of fighting the French. According to some records, it seemed that most families suffered from loss after the event. About 9,300 soldiers and civilians were killed on the spot. They were soldiers, people, officials, teachers, and so on, dying for many reasons. They might die due to the guns and bullets of the French, or due to jostling and stomping on each other while running away. They might fall when trying to climb out of the citadel or misstepped into the numerous lakes in the citadel, especially Tinh Tam Lake (An, 1972).

Thus, souls (spirits) are souls of people in the family and clan (ancestors, those who are dead); Forsaken souls can be understood as the souls of the dead without being worshiped. They may be homeless people, people with no relatives or people who had families and relatives but had to leave their homeland and died while fleeing from the war in troubled times; They can be merchants who traveled everywhere and soldiers on battlefields who unfortunately died and could not find their relatives and no one knew their names to worship every year. They can be coastal fishermen, whose lives were associated with the sea, floating, wandering on the waves, unfortunately died because of storms and their souls wandered everywhere. They became lonely souls that had no one and no place to worship.

\section{Conclusion}

Originating from different beliefs in souls, Vietnamese people have different ways to worship these souls with various forms of performance and practice. However, when entering different classes of people, these forms of worship have changed and become profound folk beliefs. Through studying the custom of worshiping souls, it can be concluded that:

The worship of souls is a socio-historical phenomenon. It is not only the behavior of the living towards their ancestors and the homeless dead, but also the behavior among those who still are living in this world.

This is a humanistic belief, demonstrating good natures of Vietnamese people: respecting affection, loving people, and feeling pity for unfortunate fates. This belief has integrated four immeasurables of Buddhism to form an extremely humanistic custom.

Apart from being a traditional spiritual ritual, with the influence of Buddhism, the worship of souls has many other meanings, including the thoughts of praying for peacefulness and good crops of inhabitants in the past and today. In human life, people always face risks, uncertainties, and catastrophes, so they need to be blessed by the dead.

So far, the worship of souls still plays a very important role in the spiritual life of Vietnamese people. Along with the development of society, this custom has changed in both positive and negative directions. However, the values that it brings are undeniable, in which there are factors of Buddhism, Taoism, and many other religions. Knowing how to select and integrate the progressive elements of foreign religions into the forms of folk beliefs, including the worship of souls, makes the beliefs more abundant and diverse.

This is a unique feature in the cultural tradition and habits and customs of the Vietnamese nation. Together with other folk beliefs, the custom of worshiping souls has also become a beauty in the diverse beliefs of Vietnamese people. Thus, in order to study the folk culture of Vietnamese people, it is necessary to study the forms of folk beliefs and the worship of souls is a typical example.

\section{Acknowledgments}

This study was supported by University of Transport and Communications, Vietnam. 


\section{Ethical Clearance}

I confirm that the paper is original unpublished work, not submitted or to be submitted for consideration elsewhere. All procedures performed in studies involving human participants were in accordance with the ethical standards in academic research.

\section{References}

Algra, K., Barnes, J., Mansfeld, J., \& Schofield, M. (1999). The Cambridge History of Hellenistic Philosophy. Cambridge: Cambridge University Press.

An, P. T. (1972). Phong Thanh Hue. Historical high school essay. Vietnam: Saigon.

Anh, T. (2005). The Custom of Worshiping in Families and Public Places in Vietnam. Hanoi: Thanhnien.

Binh, P. K. (2005). Vietnamese custom. Hanoi: Culture Information.

Bremmer, J. (1983). The Early Greek Concept of the Soul. Princeton: Princeton University Press.

Burnet, J. (1916). The Socratic Doctrine of the Soul. Proceedings of the British Academy, 7, 235-259.

Christian Timothy, H. (2013). Soul and Eternal Death. Received from https://timhieutinlanh.com/biengiao/linh-hon-va-su-chet-doi-doi/

Christopher, M. (1979). Search for the Soul: An Insider's Report on the Continuing Quest by Psychics \& Scientists for Evidence of Life after Death. Thomas Y. Crowell, Publishers.

Chu, P. H. (1992). Least-year charter schedule. Hanoi: Social Science.

Clarke, \& Peter. (2014). Neuroscience, Quantum Indeterminism and the Cartesian Soul. Brain and Cognition, 84(1), 109-117. https://doi.org/10.1016/j.bandc.2013.11.008

Claus, D. (1981). Toward the Soul, New Haven and London: Yale University Press.

Duy, P. D. (2002). Spiritual Culture. Hanoi: Culture Information.

Dzu, N. K. (1963). History of Chinese Philosophy. China: Beijing.

Frede, M. (1992). On Aristotle's Conception of the Soul. Nussbaum \& Rorty, 93-107.

Furley, D. (1956). The Early History of the Concept of Soul. Bulletin of the Institute of Classical Studies, University of London, (3), 1-18.

Giau, T. V. (1973). The Development of Thought in Vietnam from the Nineteenth Century to the August Revolution. Hanoi: Social Siences.

Hinh, N. D. (2007). Vietnamese Spirituality. Hanoi: Bach Khoa Dictionary.

History of Chinese Culture (History of Chinese Culture). (Thuan, T. N., Dat, D. D., \& Chi, D. P., Trans). (1999). Hanoi: Culture and Information.

Huong, N. X. (2009). Beliefs of coastal residents in Quang Nam - Da Nang. Hanoi: Encyclopedia \& Cultural Institute.

Huu, T. S., \& Can, T. H. (1990). Chinese Fairytales. Shanghai: Literature \& Art.

Kerferd, G. (1971). Epicurus' Doctrine of the Soul. Phronesis, 16, 80-96.

Lang, N. (1974). Vietnam Buddhism History. Saigon: La Boi.

Lien, N. S. (1689) (Edit, 2004). Dai Viet Su Ky Toan Thu (Vol. 1). Hanoi: Social Science.

Lien, N. S. (1689) (Edit, 2004). Dai Viet Su Ky Toan Thu (Vol. 2). Hanoi: Social Science.

Lorenz, H. (2008). Plato on the Soul. In G. Fine (Ed.), The Oxford Handbook of Plato. Oxford: Oxford University Press.

Max Planck. (1937). Religion and Natural Science. Received from https://archive.org/stream/in.ernet.dli.2015.177537\#page/n151/mode/2up

Ngoc, P. (2002). Vietnamese Cultural Identity. Hanoi: Literature.

Phe, H. (2005). Vietnamese Dictionary. Vietnam: Danang.

Sam, H. P. (1995). Chinese Taoism great Dictionary. China: Shanghai.

San, N. M. (1998). Access to Vietnamese Folk Beliefs. Hanoi: Ethnic Culture. 
Santoro, G., Wood, M. D., Merlo, L., Anastasi, G. P., Tomasello, F., \& Germanò, A. (2009). The anatomic location of the soul from the heart, through the brain, to the whole body, and beyond: A journey through Western history, science, and philosophy. Neurosurgery, 65(4), 633-643. https://doi.org/10.1227/01.NEU.0000349750.22332.6A

Sarao, K. T. S., \& Long, J. D. (2017). "Jīva (Jainism)". Buddhism and Jainism. Encyclopedia of Indian Religions (p. 594). Springer Netherlands. https://doi.org/10.1007/978-94-024-0852-2_10039

Swinburne, R. (1997). The Evolution of the Soul. Oxford: Oxford University Press.

Tham, H. B. (2014). Realizing the Nature of Consciousness and Spirituality. Received from https://www.chungta.com/nd/tu-lieu-tra-cuu/nhan-thuc-lai-ban-chat-cua-y-thuc-va-tam-linh.html

Thanh, D. (Edit, 2018). Tho Mai Gia Le. Thanh Hoa: Hong Duc

Thu, N. T. (1997). The Influence of Ideologies and Religions on Vietnamese People today. Hanoi: National Politics.

Tien Duc Association. (1931). Vietnam Dictionary. Saigon: Mac Lam.

Tocarev, X. A. (1994). Early Religious Forms and their Development. Vietnam: Hanoi.

Trang, H. N., \& Tuong, T. N. (1999). Nam Bo Temple Ancient and Present. Vietnam: Dong Nai.

Tylor, E. B. (2000). Original Culture. Hanoi: Art and Culture.

Watson, W. H. (1997). Soul and System: The Integrative Possibilities of Family Therapy. Journal of Psychology and Theology, 25(1), 123-135. https://doi.org/10.1177/009164719702500112

Y, N. N., \& Huy, C. (2011). Cultural Dictionary, Traditional Vietnamese Customs. Hanoi: Vietnam Education.

\section{Copyrights}

Copyright for this article is retained by the author(s), with first publication rights granted to the journal.

This is an open-access article distributed under the terms and conditions of the Creative Commons Attribution license (http://creativecommons.org/licenses/by/4.0/). 